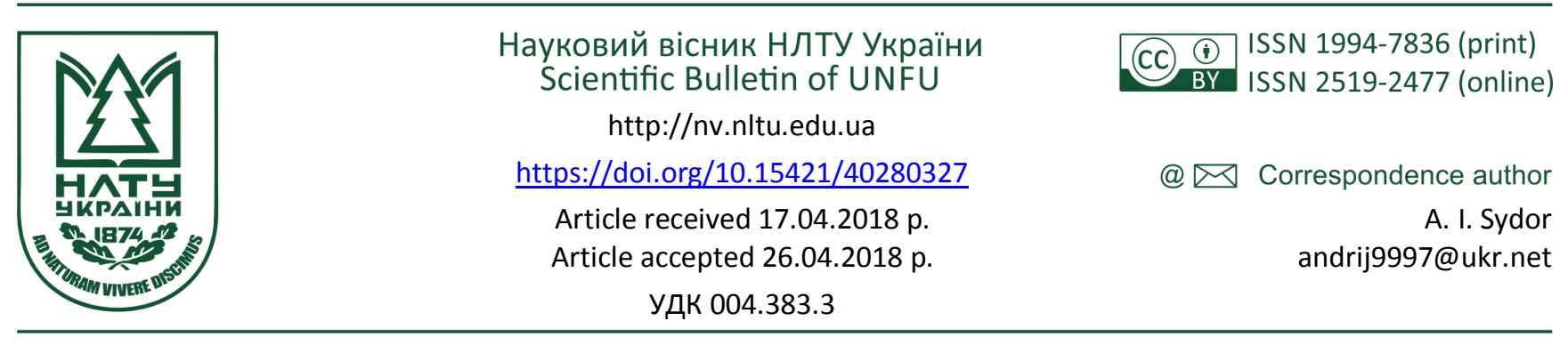

А. І. Сидор ${ }^{1}$, О. П. Люра ${ }^{2}$, Я. М. Николайчук ${ }^{1}$

${ }^{1}$ Тернопільський національний економічний університет, м. Тернопіль, Украйна

${ }^{2}$ Івано-Франківський національний технічний університет нафти і газу, м. Івано-Франківськ, Україна

\title{
ТЕОРЕТИЧНІ ЗАСАДИ ТА ЗАДАЧІ РОЗПІЗНАВАННЯ ГАРМОНІЧНИХ СИГНАЛІВ ТА ОБРАЗІВ НА ОСНОВІ ОЦІНКИ ХЕММІНГОВОЇ ВІДДАЛІ
}

\begin{abstract}
Розв'язано задачу розпізнавання гармонічних сигналів та образів на основі оцінки Хеммінгової віддалі, що виникає під час виникнення збурень у високовольтних лініях електропересилень типу накидів, замикань на землю та запусків потужних електроприладів. Проаналізовано основні переваги та недоліки виробників мікроконтролерних засобів релейного захисту. Розроблено теоретичні засади диференціально-різницевого алгоритму розпізнавання накидів і коротких замикань у лініях електропересилань. Розроблено структуру та функціональну схему спецпроцесора розпізнавання збурень у високовольтних лініях електропересилань на основі кореляційної оцінки Хеммінгової віддалі. Проведено дослідження часової складності спецпроцесора визначення Хеммінгової віддалі у теоретико-числовому базисі Радемахера. Виконано постановку задачі динамічного опрацювання цифрових сигналів на основі визначення Хеммінгової віддалі до джерела акустичних сигналів. Розроблено принципи структурної побудови та структурних рішень спецпроцесора кореляційного опрацювання акустичних сигналів. Розроблено структурні рішення спецпристрою визначення Хеммінгової віддалі у базисах Радемахера та Хаара, його структуру та базові компоненти. Сформовано принципи роботи спецпроцесора визначення Хеммінгової віддалі у теоретико-числових базисах Радемахера та Хаара.
\end{abstract}

Ключові слова: лінії електропересилань; спецпроцесор; теоретико-числовий базис; джерело акустичних сигналів; релейний захист.

Вступ. У процесі експлуатації високовольтних ліній електропересилань (ЛЕП) можуть виникати особливі перехідні режими та можливість виникнення пошкоджень обладнання електричних i трансформаторних підстанцій. Такі пошкодження призводять до механічного виводу з ладу технологічного обладнання струмами короткого замикання або дугою, яка виникає у місці пошкодження (Kidyba, 2015).

Пересилання електричних потужностей у високовольтних ЛЕП здійснюються на основі енергії трьохфазних гармонічних сигналів, промислової частоти 50 Гц.

Задача розпізнавання гармонічних сигналів та образів на основі оцінки Хеммінгової віддалі (Krulikovskyi et al., 2016, 2017) виникає під час виникнення збуджень у високовольтних лініях електропересилень типу накидів, замикань на землю та запусків потужних електроприладів (ПЕД) (Nykolaichuk, 2010).

Класично системи релейного захисту будуються на принципі порогового вимірювання стрибка фазного струму. Водночас виникають ситуації в електромережах, коли стрибок фазного струму при накидах та запусках ПЕД є набагато більшим порівняно із стрибком фазного струму при виникненні замикань на землю на далекій віддалі від електричної підстанції. У цьому випадку реле захисту неправильно спрацьовує, що призводить до неможливості підтримки потужного споживання електроенергії або недоступної часової затримки при розвитку замикання на землю.

За останні два десятки років в Україні впроваджено засоби релейного захисту, що виконані на основі цифрових принципів опрацювання сигналів та розпізнавання образів.

Відомі зарубіжні фірми: АBB, Siemens, Alstorn, General Electric, Schneider, Areva, Nari, Vamp, Релсіс та інші серійно випускають та масово впроваджують мікроконтролерні засоби релейного захисту ЛЕП.

В Україні виробниками мікроконтролерних засобів релейного захисту є: Київприлад, Радіус Автоматика, IMCКОЕ та ін. (Sabadash, 2011).

Мікроконтролерні засоби релейного захисту мають такі основні переваги: вища точність (до $2 \%$ ) відтворення заданих характеристик функціонування засобу релейного захисту; забезпечення коефіцієнта повернення (до 0,99), що потребує складних технічних рішень в інших типах пристроїв релейного захисту; реалізація

\section{Інформація про авторів:}

Сидор Андрій Іванович, аспірант, кафедра спеціалізованих комп'ютерних систем. Email: andrij9997@ukr.net

Люра Олег Петрович, аспірант, кафедра комп'ютерних систем та мереж. Email: oleg.lura14@gmail.com

Николайчук Ярослав Миколайович, д-р техн. наук, професор, завідувач кафедри спеціалізованих комп'ютерних систем. Email: ya.nykolaichuk@tneu.edu.ua

Цитування за ДСтУ: Сидор А. І., Люра О. П., Николайчук Я. М. Теоретичні засади та задачі розпізнавання гармонічних сигналів та образів на основі оцінки Хеммінгової віддалі. Науковий вісник НлтУ України. 2018, т. 28, № 3. С. 131-136.

Citation APA: Sydor, A. I., Liura, O. P., \& Nykolaichuk, Ya. M. (2018). Theoretical Foundations and Tasks of Recognition of Harmonic Signals and Images on the Basis Estimation of Hemming Distance. Scientific Bulletin of UNFU, 28(3), 131-136. https://doi.org/10.15421/40280327 
програмним шляхом характеристик спрацювання будьякої складності; запам'ятовування координат режиму під час спрацювання цифрового пристрою; можливість оперативного, зокрема і дистанційного, алгоритму опрацювання сигналів; універсальність застосування у вирішенні різних задач захисту від перевантажень та коротких замикань у технологічному обладнанні ЛЕП; менші габарити та монтажні затрати; можливість самодіагностики та моніторинг надійності; менше споживання енергії, що істотно зменшує потужність джерел енергії оперативного струму; менші експлуатаційні затрати на профілактичні роботи, які виконуються шляхом тестування програмного забезпечення.

Досвід експлуатації такого класу пристроїв релейного захисту дав змогу встановити також низку негативних особливостей та функціональних обмежень: зниження надійності та довговічності, зумовлене характеристиками безвідмовності базових компонентів мікроконтролерних реалізацій: АЦП, мікропроцесора, інтерфейсів вводу/виводу та живлення; значна концентрація в одному пристрої багатьох важливих функцій моніторингу стану промислового обладнання ЛЕП, наприклад потужних трансформаторів.

Теоретичні засади розпізнавання гармонічних сигналів під час збурень у ЛЕП. Опрацювання гармонічних сигналів під час збурень у ЛЕП диференціальноінтегральним методом базується на поточному обчислені модульної різниці між двома сигналами $S_{1}(t)$ та $S_{0}(t)$, які реєструються в часі із зсувом на півперіоди промислової частоти згідно з виразом: $H(t)=\left|S_{1}(t)\right|-\left|S_{0}(t)\right|$.

Інтегрування модульної різниці сигналів виконується цифровим способом згідно з виразом:

$$
\begin{aligned}
H(t) & =\Delta t \cdot \sum_{i=j}^{\pi / 2+j}\left|S_{i}(\Delta t)\right|-\Delta t \cdot \sum_{k=\pi / 2+j}^{\pi+j}\left|S_{k}(\Delta t)\right|= \\
& =\Delta t \cdot\left(\sum_{i=j}^{\pi / 2+j}\left|S_{i}(\Delta t)\right|-\sum_{k=\pi / 2+j}^{\pi+j}\left|S_{k}(\Delta t)\right|\right)
\end{aligned} .
$$

Якщо значення знайдених рівностей дорівнюють нулю, то процеси, які відбуваються в системі, є стабільними.

Коли ж $H(t)>0$, тоді відбуваються певні нерівноважні процеси, що вказує на виникнення передаварійних станів у системі. Для дискретних процесів $H_{j}^{0}=\frac{S_{j+\pi / 2}-S_{j}}{\Delta t}, \quad$ де $\quad \Delta t=\frac{\pi}{2}, \quad j=\frac{\pi n}{2}, n=0,1,2, \ldots$ $H_{j}^{1}=\frac{S_{j+\pi}-S_{j+\pi / 2}}{\Delta t} \cdot$ Звідси

$$
H(t)=|| H_{j}^{1}|-| H_{j}^{0}||=|| \frac{S_{j+\pi}-S_{j+\pi / 2}}{\Delta t}|-| \frac{S_{j+\pi / 2}-S_{j}}{\Delta t} \mid .
$$

Якщо значення знайдених рівностей дорівнюють нулю, то процеси, які відбуваються в системі, є стабільними. Коли ж $H(t)>0$, тоді відбуваються певні нерівноважні процеси, що вказує на виникнення передаварійних станів у системі.

Для виконання різницевого імпульсно-квадратичного методу потрібно рекурентно (у стековому режимі) запам'ятовувати цифрові відліки $x_{i}$ у регістрі пам'яті $x_{i} \rightarrow x_{i-1} \rightarrow x_{i-2} \ldots \rightarrow x_{i-j} . . \rightarrow x_{i-n}$ і різницево порівнювати ці запам'ятовані значення з текучими відліками $x_{i}$. Тобто згідно 3 зі схемою $\rightarrow x_{i} \rightarrow x_{i-1} \rightarrow x_{i-2 \ldots} \rightarrow$ $\rightarrow x_{i-j} \ldots \rightarrow x_{i-n} \Rightarrow x_{i}-x_{i-n}$. Внаслідок виконання такої операції у ковзному режимі 3 кроком $\Delta t$ отримаємо $Z_{i}=\left|x_{i}-x_{i-n}\right|$, де модульна операція враховує симетрію зміни амплітуд струмів у напрямі зростання при накиді та спадання при скиді навантаження в електромережі.

Реакція процесора буде мати зміну амплітуди струму у момент стрибка: $A_{1} \rightarrow A_{2} ; A_{1}<A_{2}$ на інтервалі півперіоду, але $\epsilon$ інваріантна до можливих інших більших чи менших стрибків амплітуди струму в інші моменти часу, тобто

$$
Z_{i}=\left\{\begin{array}{l}
0, t \leq t_{0} ; \\
\left(A_{2}-A_{1}\right) \sin \omega t, t_{0} \leq t \leq t+\pi / 2 ; \\
0, t>t_{0}+\pi / 2
\end{array}\right.
$$

Для підвищення чутливості та прийнятої здатності ідентифікації факту короткого замикання на початковій стадії його розвитку, а також спрощення алгоритму обчислень та структури спецпроцесора, на інтервалі часу $t>t_{0}+\pi / 2$ доцільно застосувати квадратично-імпульсний метод цифрового опрацювання даних $Z_{i}$ згідно з виразом:

$$
S_{\kappa .3 .}=\left\{\begin{array}{l}
1, \text { якщо } Z_{i}^{2}\left(t>t_{0}+\pi / 2\right)>P_{0} ; \\
0, \text { якщо } Z_{i}^{2}\left(t>t_{0}+\pi / 2\right)<P_{0},
\end{array}\right.
$$

де: $P_{0}$ - порогове значення, яке вибирається експертним шляхом або у процесі багаторазових випробувань на реальних прикладах. Цей поріг $P_{0} \in$ інваріантний до величини стрибка струму $A_{2}>A_{1}=$ var, тобто не залежить від можливої різниці $\Delta=\left|A_{2}-A_{1}\right|$ у момент виникнення збурення $t_{0}$. Оскільки у випадку накиду коефіцієнт експоненти $\alpha \approx 0$ і на інтервалі часу $t_{0}>t_{0}+\pi / 2$ $Z_{i} \approx 0$.

Розроблення структури та функціональної схеми спецпоцесора розпізнавання збурень у високовольтних ЛЕП. На рис. 1 показано структурну схему пристрою (Liura \& Vozna, 2017), який оснащений трансформаторами напруги (T1) та струму (T2), двохпівперіодними випрямлячами, аналого-цифровими перетворювачами (АЦП), ідентифікатором різниці фаз, пристроєм ідентифікації накидів та к. з. (коротких замикань) i логічною схемою (ЛС), три виходи якої формують сигнали зростання силових величин: $\mathrm{N}$ - накид, $\mathrm{C}-\mathrm{K} 3$, $\mathrm{Z}$ - запуск ПЕД.

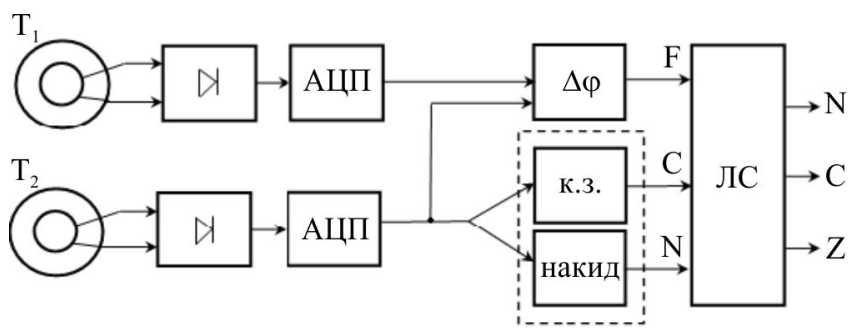

Рис. 1. Структурна схема пристрою ідентифікації накидів, замикань на землю та запусків потужних електроприводів у ЛЕП

Розпізнавання таких сигналів та ідентифікація відповідних ознак перехідних процесів у ЛЕП виконуються шляхом піднесення до квадрата оцифрованих гармонічних сигналів $\pm x_{i} \rightarrow x_{i}^{2}$ (рис. 2) та кореляційного інтегрально-імпульсного опрацювання цих сигналів на основі оцінки Хеммінгової віддалі між двома зсунутими на півперіоди промислової частоти 50 Гц цифровими сигналами згідно з виразом 


$$
S_{i}=\frac{1}{n} \sum_{i=1}^{n}\left|x_{i}^{2}-x_{i-j}^{2}\right| \leq P_{0},
$$

де $P_{i}$ - порогова оцінка границі оцінки Хеммінгової віддалі.
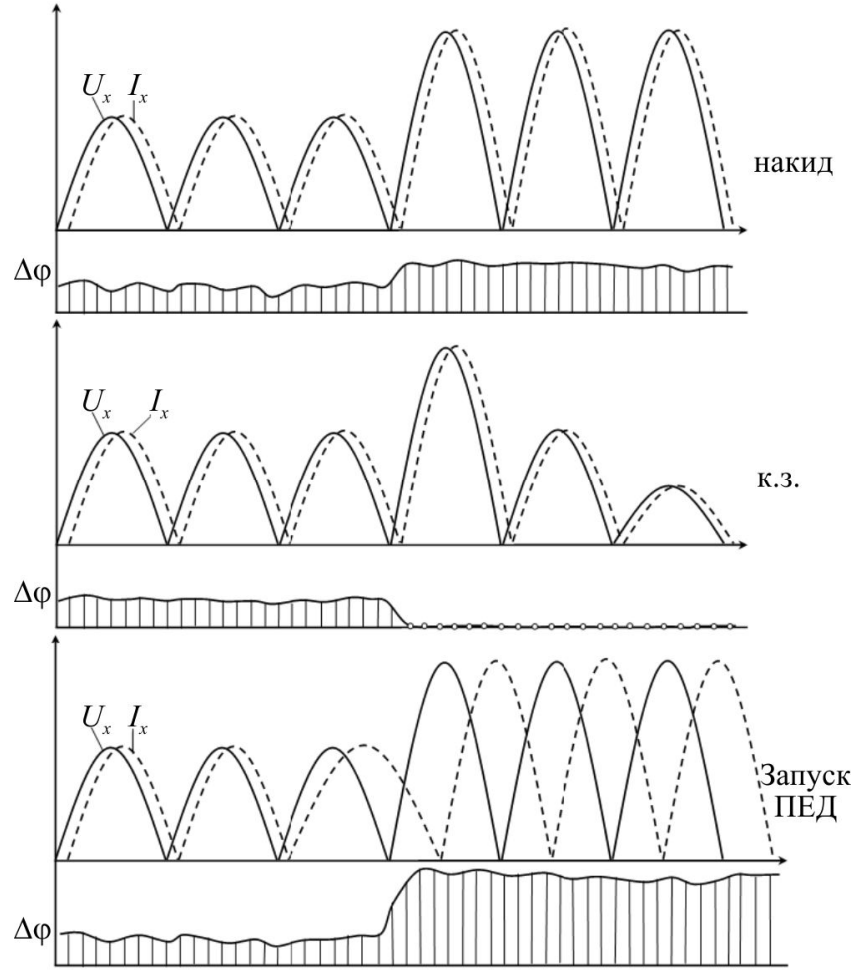

Рис. 2. Часові діаграми випрямлених значень фазної напруги, струму та різниці фаз $\Delta \varphi$ при накидах, КЗ та запуску ПЕД У високовольтних ЛЕП

Оцифровані значення гармонічних сигналів на виході АЦП представляються в унітарному теоретико-числовому базисі та опрацьовуються число-імпульсним спецпроцесором, структуру якого показано на рис. 3 (Liura et al., 2016).

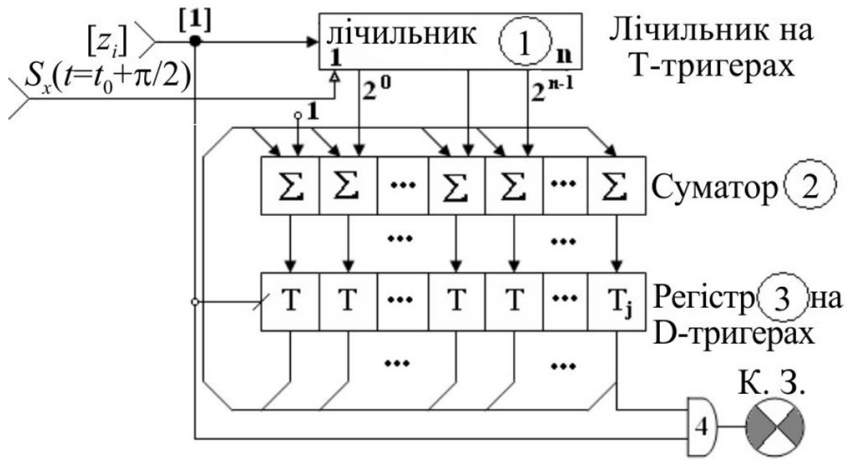

Рис. 3. Структура імпульсного спецпроцесора на основі порогового інтегрального квадратора

Обчислення виконуються згідно з алгоритмом

$$
x_{i}^{2}=\sum_{i=1}^{n} 2 i+1
$$

тобто суми непарних чисел, яка дорівнює квадрату вхідного числа імпульсів.

Робота та дослідження часової складності спецпроцесора визначення Хеммінгової віддалі у теоретико-числовому базисі Радемахера. У випадку, коли цифрові значення квадратів гармонічних сигналів, які формуються двохпівперіодним випрямлячем та АЦП паралельного типу з вихідними кодами у базисі Радемахера, інтегруюча порогова оцінка Хеммінгової віддалі здійснюється пристроєм додавання багаторозрядних двійкових чисел, структуру якого показано на рис. 4 (Trembach et al., 2017).

Пристрій містить: 1, 2 - відповідна вхідна $2 k$-розрядна та вихідна $k+m$-розрядна шини; $3-k+m$-розрядний накопичувальний суматор; $4-k+m$-розрядний паралельний регістр; 5, 6 та 7 - відповідно вхід синхронізації запису, вхід синхронізації скиду у нуль та вхід синхронізації запису; 8 - $D$-тригери паралельного регістра; 9.1 та 9.2 - однорозрядні повні суматори відповідно першого та другого $k$-розрядних суматорів; 10 - вхід логічної одиниці; 11 - розрядні компоненти мультиплексора; 12 - вхід логічного нуля.

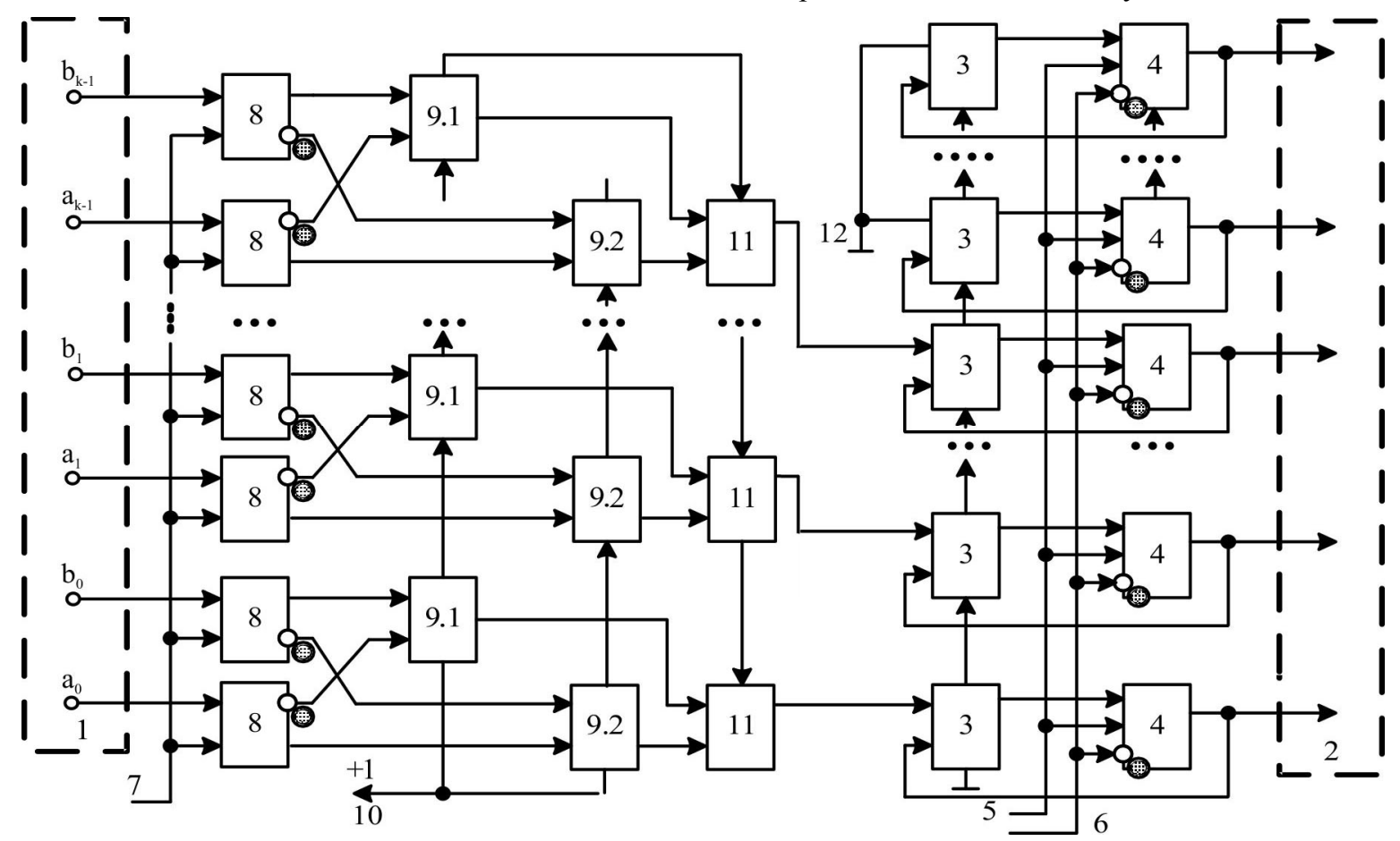

Рис. 4. Структурна схема спецпроцесора визначення Хеммінгової віддалі у ТЧБ Радемахера 
На початку роботи пристрою після подачі сигналу синхронізації у вигляді фронту наростання на вхід синхронізації 6 скиду у нуль $k+m$-розрядного паралельного регістра 4 на вихідній $k+m$-розрядній шині 2 формується двійкове число нуль, яке також надходить на перші входи $k+m$-розрядного накопичувального суматора 3.

Спецпроцесор працює шляхом додавання у двох суматорах прямих і доповнювальних кодів вхідних чисел та управління мультиплексором сигналами із старшого виходу одного з суматорів, який керується мультиплексором, на виході якого формується код модульної різниці між двома вхідними числами. У накопичувальному суматорі (3) реєструється сума модульних різниць, яка відповідає оцінці Хеммінгової віддалі.

Розрахунок часової складності для запропонованого спецпроцесора такий $\tau=\tau_{P 1}+n \cdot \tau_{C}+\tau_{M \Pi}+2 n \cdot \tau_{H C}+\tau_{P 2}$, а тдля інших - такі значення:

$$
\tau=\left\{\begin{array}{l}
2+4+3+8+2=19 v, \text { якщо } n=4 ; \\
2+8+3+16+2=31 v, \text { якщо } n=8 ; \\
2+10+3+20+2=37 v, \text { якщо } n=10 ; \\
2+12+3+24+2=43 v, \text { якщо } n=12 ; \\
2+16+3+32+2=55 v, \text { якщо } n=12 .
\end{array}\right.
$$

Розроблення теоретичних основ структурних рішень спецпроцесора кореляційного опрацювання акустичних сигналів. Актуальною задачею динамічного опрацювання цифрових сигналів на основі визначення Хеммінгової віддалі $є$ визначення віддалі до джерела акустичних сигналів (ДАС) (Nykolaichuk, 2012).

Існують два методи визначення віддалі до ДАС. Перший метод базується на тому, що при заданій базі, яка представляє відстань між двома акустичними сигналами $B A=L_{0}$ визначається кут похилу до ДАС за рахунок обчислення різниці між часом сприйняття акустичних сигналів двох приймачів акустичних сигналів (ПАС), згідно з виразом (Trembach, 2016):

$$
\sin (C A B)=\sin (N D O)=\frac{B C}{B A}=\frac{\left(t_{2}-t_{1}\right) \cdot c}{B A}=\frac{\Delta t \cdot c}{L_{0}},
$$

де: $B C$ та $C A$ - катети прямокутного трикутника $\mathrm{ABC}$; відрізок $B A$ - його гіпотенуза; кут NDO дорівнює куту $\mathrm{CAB} ; t_{1}, t_{2}$ - час приймання сигналів від ДАС; $c$ - швидкість поширення звуку в просторі; $\Delta t-$ різниця часу реєстрації звуку двома приймачами.

Обчислення такого алгоритму визначення відстані до ДАС потребує виконання операції множення $\Delta t \cdot c$.

Оптимізація такого алгоритму обчислення кута та відстані до ДАС досягається вибором базової відстані $L_{0}$, що дорівнює $2^{n}$, що дає змогу замінити операцію ділення на $L_{0}$ шляхом відкидання заданого числа біт молодших розрядів. Іншим методом, яким можна спростити цей алгоритм обчислення завдання $L_{0}, \epsilon$ прийняття швидкості поширення звуку в атмосфері $c=330 \mathrm{~m} / \mathrm{c}$, або вибрати $L_{0}=k^{*} c$, що дасть змогу повністю виключити операцію ділення 3 виразу та обчислити згідно 3 виразом: $\sin (C A B) k * \Delta t$, що істотно спрощує цифрову реалізацію спецпроцесора.

Другий метод визначення віддалі до цілі базується на визначені рівня затухання акустичних сигналів на різних віддалях від ДАС. Математичною формалізацією такої задачі є розрахунки згідно з виразом (Trembach, 2016):

$$
P_{L_{x}}=P_{0} * e^{-\alpha L_{x}}, L_{x}=L_{0}+\frac{\log \Delta P}{\alpha} \text { або } L_{x}=L_{0}+\frac{\log \Delta P}{k \alpha},
$$

де: $P_{0}, P_{\alpha}-$ відповідні потужності у різних відповідних точках прийняття акустичних сигналів; $\Delta P$ - різниця між потужностями сигналів; $\mathrm{k}$ - коефіцієнт, що враховує перехід до двійкового алгоритму.

При цьому, якщо добуток $k \cdot \alpha$ буде дорівнювати $2^{n}$, то операція ділення цифрового двійкового коду на цей добуток буде виконуватися шляхом відкиданням $n$ розрядів від коду.

У роботі (Trembach, Sydor \& Vozna, 2017) наведено приклад структури кореляційного спецпроцесора розпізнавання та визначення віддалі до ДАС, який на полігоні двохвимірного Хеммінгового простору задається у декартових координатах.

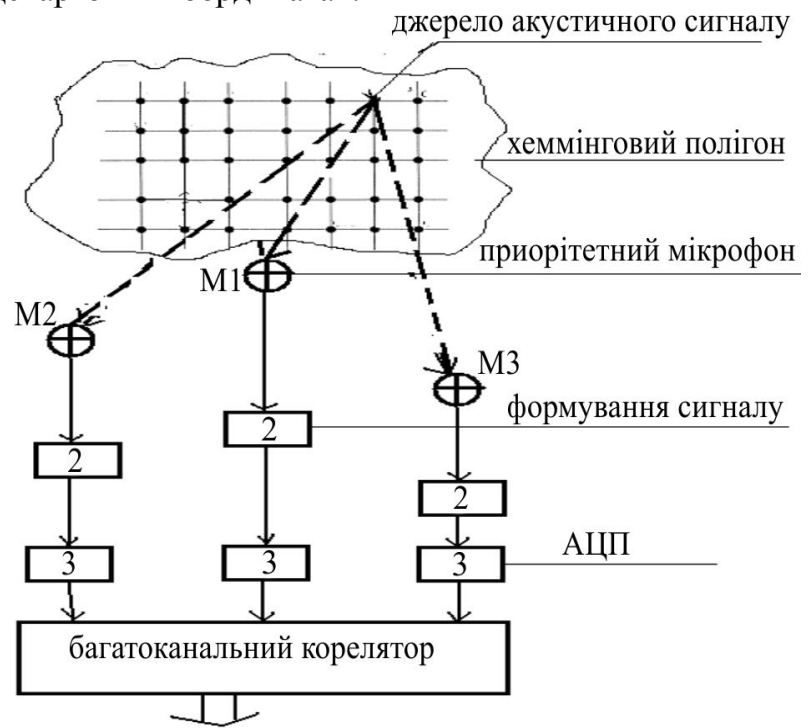

Рис. 5. Базова структура цифрового спецпроцесора кореляційного опрацювання акустичних сигналів

На рис. 5 наведено структуру кореляційного спецпроцесора, який містить: 1) мікрофони, які розміщені на фіксованій відстані один від одного і приймають звук від акустичного джерела сигналу; 2) пристрої, що обробляють сигнал; 3) аналогово-цифрові перетворювачі (АЦП); 4) багатоканальний корелятор, в ролі якого може використовуватися схемаспецпроцесор визначення Хеммінгової віддалі у ТЧБ Радемахера.

Базовим компонентом такого спецпроцесора є пристрій додавання багаторозрядних двійкових чисел, структуру якого показано на рис. 4, який накопичує інтегральну оцінку інвертованої Хеммінгової віддалі між часовими розгортаннями поточних $S_{i}, S_{j}$ та затриманого у багаторозрядному регістрі зсуву стартового $S_{i-j}$ сигналу прийнятого від пристрою пріоритетно розміщеного мікрофона $M_{0}$.

У кожному каналі при $\bar{d}_{i j}=0,25 \sum\left|x_{i}^{2}-x_{i-j}^{2}\right| \rightarrow 0$ формуються коди $\Delta t_{1}, \Delta t_{2}$ та $\Delta t_{3}$ - часових затримок між мікрофонами $M_{1}, M_{2}$ та $M_{3}$, на основі яких здійснюється на виході ПЗП пеленгація ДАС у вузлах Хеммінгового полігону.

Розроблення структурних рішень спецпристрою визначення Хеммінгової віддалі у базисах Радемахеpa та Хаара. У випадку, коли застосовується АЦП у базисі Хаара, оцінка Хеммінгової віддалі реалізується на основі спецпроцесора визначення Хеммінгової від- 
далі між двома сигналами, структуру якого показано на рис. 6 i 7.

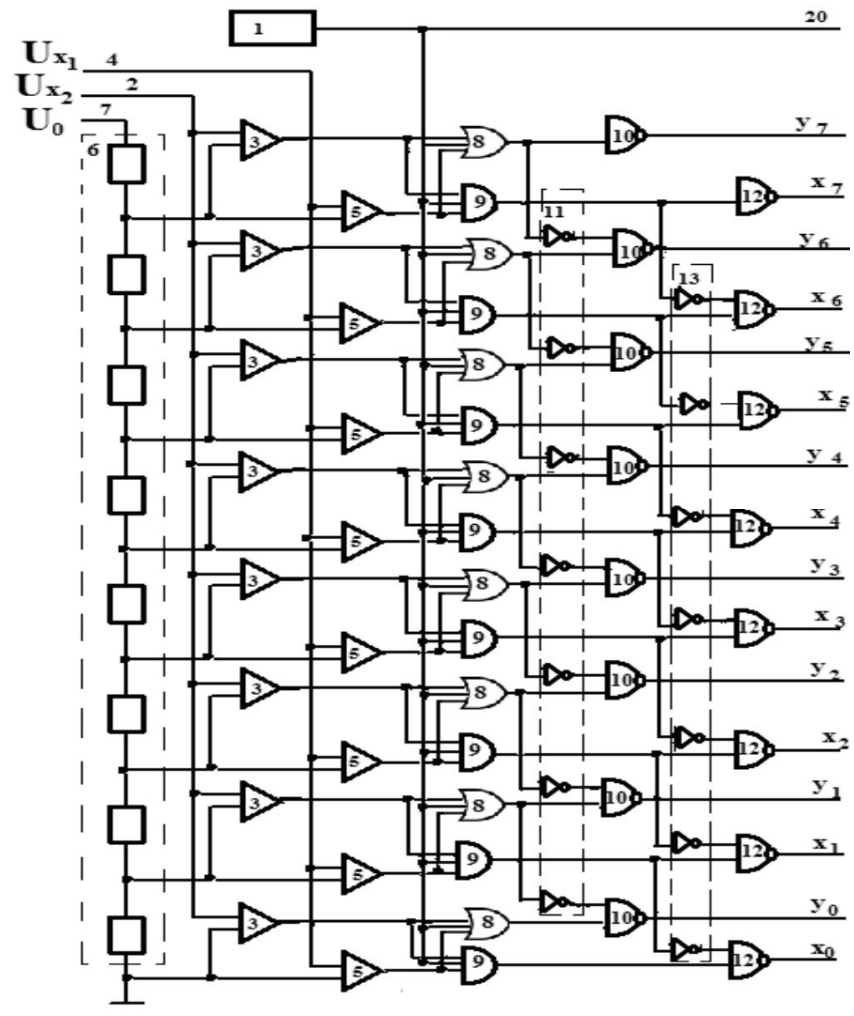

Рис. 6. Структурна схема пристрою визначення Хеммінгової віддалі між двома сигналами (початок)

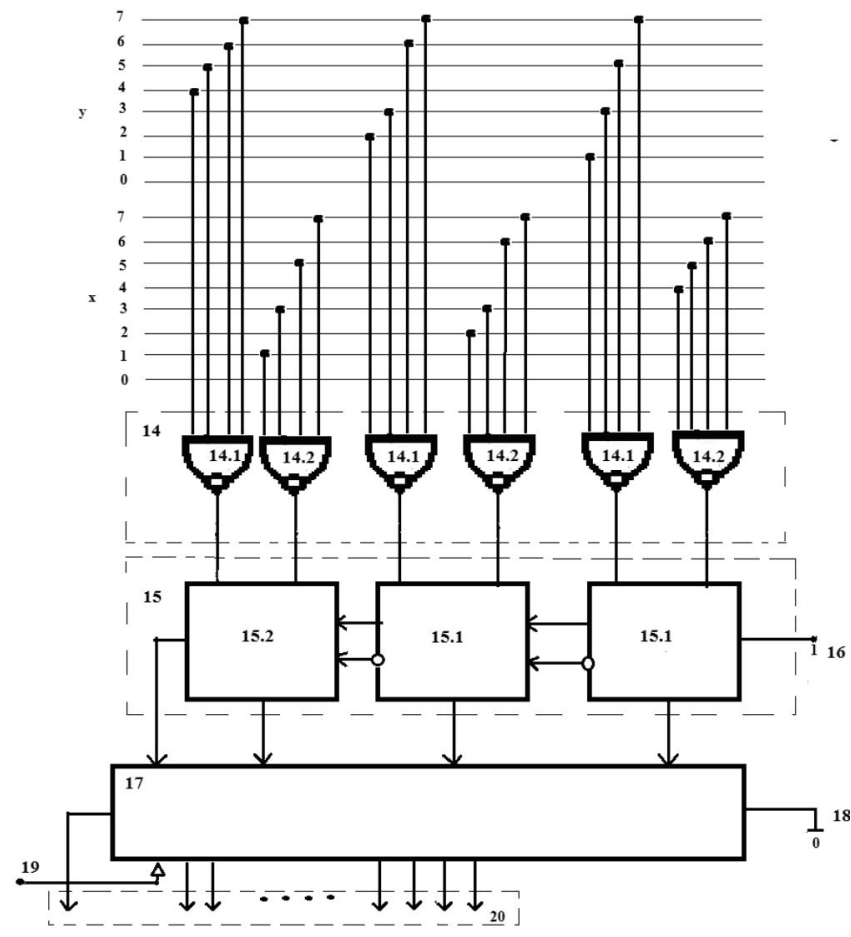

Рис. 7. Структурна схема пристрою визначення Хеммінгової віддалі між двома сигналами (кінець)

Пристрій містить: 1) синхронізатор; 2) перший аналоговий вхід; 3) перший компаратор $i$-го розряду; 4) другий аналоговий вхід; 5) другий компаратор $i$-го розряду; 6) схема формування ступінчастих взірцевих потенціалів; 7) вхід схеми формування ступінчастих взірцевих потенціалів; 8) логічний елемент АБО; 9) логічний елемент I; 10) перший логічний елемент I-HE; 11) перший логічний елемент $\mathrm{HE} ; 12)$ другий логічний елемент I-HE; 13) другий логічний елемент HE; 14) тре- тій логічний елемент I-HE; 15) перший багаторозрядний суматор; 16) парафазний вхід логічної 10 ; 17) накопичувальний суматор; 18) вхід логічного 0; 19) вхід скиду в 0 накопичувального суматора; 20) вхід синхронізації накопичувального суматора $17 ; 21)$ вихідна шина пристрою.

Робота пристрою полягає в тому, що вхідні аналогові сигнали у двоканальному АЦП паралельного типу перетворюються у паралельні унітарні коди, які однозначно представляють більше та менше значення $x_{i}$ та $y_{i}$, після чого перетворюються у паралельні інверсні розрядопозиційні коди Хаара, де шифруються у відповідні: прямий двійковий код більшого 3 них, та доповнювальний код меншого 3 них, які додаються у швидкодіючому багаторозрядному накопичувальному суматорі.

Висновок. У роботі розглянуто основні переваги та недоліки виробників мікроконтролерних засобів релейного захисту. Розроблено структуру та функціональну схему спецпроцесора розпізнавання збурень у високовольтних лініях електропересилань. Охарактеризовано роботу та проведено дослідження апаратної та часової складності спецпроцесора визначення Хеммінгової віддалі у теоретико-числовому базисі Радемахера. Розроблено структурні рішення спецпристрою визначення Хеммінгової віддалі у базисах Радемахера та Хаара. Розроблені спецпроцесори мають низку своїх переваг та недоліків. Подальшим розвитком пристроїв розпізнавання гармонічних сигналів та образів на основі оцінки Хеммінгової віддалі під час виникнення збурень у високовольтних лініях електропересилань типу накидів, замикань на землю та запусків потужних електроприладів $\epsilon$ розробка спецпроцесора визначення Хеммінгової віддалі у теоретико-числовому базисі Хаара-Крестерсона, що характеризується більшою швидкодією порівняно 3 наявними аналогами.

\section{Перелік використаних джерел}

Kidyba, V. P. (2015). Releinyi zakhyst elektroenerhetychnykh system. Lviv: Vydavnytstvo Lvivskoi politekhniky. 504 p. [In Ukrainian].

Krulikovskyi, B. B., Sydor, A. I., Nykolaichuk, Ia. M., \& Zastavnyi, O. M. (2016). Some Methods for Determining the Parameters of Mathematical Models of Forest Growth. Scientific Bulletin of UNFU, 26(3), 361-367. https://doi.org/10.15421/40260360

Krulikovskyi, B. B., Sydor, A., Zastavnyy, O., \& Nykolaichuk, Yu. (2017). Method for Multidimensional Patterns Recognition in Hamming Spase. CADSM'2017, Lviv Ukraina, (pp. 195-198). [In Ukrainian].

Liura, O. P., \& Vozna, N. Ya. (2017). Research and optimization of the components of microelectronic devices of relay in high-voltage lines. Scientific Bulletin of UNFU, 27(5), 148-154. https://doi.org/10.15421/40270529

Liura, O., Ostrovka, I., Sabadash, I., Nykolaichuk, Ya. (2016). Theoretical Principles and Methods of Distortions Recognition in Load Surges, Short Circuits and Powerful Electric Drives Launching Type Power Lines. Proceedings of the XIII the International Conference, (pp. 33-36) (TCSET'2016).

Nykolaichuk, Ya. M. (2010). Teoriia dzherel informatsii. (2nd ed.). Ternopil: Ternohraf. 534 p. [In Ukrainian].

Nykolaichuk, Ya. M. (2012). Kody polia Halua: teoriia ta zastosuvannia. Ternopol: Ternohraf. 575 p. [In Ukrainian].

Sabadash, I. O. (2011). Novitni mikroprotsesorni tekhnolohii v ekspluatatsii merezh 6-36 kV. Elektrycheskye sety v systemy, 6, 34 39. [In Ukrainian].

Trembach, B. R. (2016). Metod vyznachennia viddali do dzherela akustychnykh syhnaliv. Lviv: Vydavnytstvo Lvivskoi politekhniky "Kompiuterni systemy ta merezhi". 110 p. [In Ukrainian]. 
Trembach, B. R. Sydor, A. I., \& Vozna, H. V. (2017). Metody identyfikatsii dzherel akustychnykh syhnaliv u dvovymirnomu Khemminhovomu prostori, (pp. 86-89), (ACIT2017). Ternopil. [In Ukrainian].

Trembach, R. B., Trembach, B. R., Sydor, A. I., \& Vozna, H. V. (2017). Struktura ta systemni kharakterystyky spets protsesoriv vyznachennia Khemminhovoi viddali Realizovani v riznykh teoretyko-chyslovykh bazysakh. Mathematical and Computer Modelling Series: Technical sciences, (pp. 244-250). KamianetsPodilsk Ukraina.

\author{
А. И. Сыдор ${ }^{1}$, О. П. Люра ${ }^{2}$, Я. М. Николайчук ${ }^{1}$ \\ ${ }^{1}$ Тернопольский национальный экономический университет, г. Тернополь, Украина \\ ${ }^{2}$ Ивано-Франковский национальный технический университет нефти и газа, г. Ивано-Франковск, Украина
}

\title{
ТЕОРЕТИЧЕСКИЕ ОСНОВЫ И ЗАДАЧИ РАСПОЗНАВАНИЯ ГАРМОНИЧЕСКИХ СИГНАЛОВ И ОБРАЗОВ НА ОСНОВЕ ОЦЕНКИ ХЕММИНГОВОГО РАССТОЯНИЯ
}

Приведено решение задачи распознавания гармонических сигналов и образов на основе оценки Хеммингового расстояния, возникающей при возникновении всплесков в высоковольтных линиях электропередач типа накидов, замыканий на землю и запусков мощных электроприборов. Проанализированы основные преимущества и недостатки производителей микроконтроллерных средств релейной защиты. Разработаны теоретические засады дифференциально-разностного алгоритма распознавания накидов и коротких замыканий в линиях электропередач. Разработаны структура и функциональная схема спецпроцессора распознавания всплесков в высоковольтных линиях электропередач на основе корреляционной оценки Хеммингового расстояния. Проведено исследование аппаратной и временной сложности спецпроцессора определения Хеммингового расстояния в теоретико-числовом базисе Радемахера. Исполнена постановка задачи динамической обработки цифровых сигналов на основе определения Хеммингового расстояния к источнику акустических сигналов. Разработаны принципы структурного построения и структурных решений спецпроцессора корреляционной обработки акустических сигналов. Разработаны структурные решения спецустройства определения Хеммингового расстояния в базисах Радемахера и Хаара, его структура и базовые компоненты такого спецпроцессора. Поэтапно рассмотрены принципы работы спецпроцессора определения Хеммингового расстоянии в теоретико-числовых базисах Радемахера и Хаара.

Ключевые слова: линии електропередач; спецпроцессор; теоретико-числовой базис; источник акустических сигналов; релейная защита.

\author{
A. I. Sydor', O. P. Liura², Ya. M. Nykolaichuk ${ }^{1}$ \\ ${ }^{1}$ Ternopil National Economic University, Ternopil, Ukraine \\ ${ }^{2}$ Ivano-Frankivsk National Technical University of Oil and Gas, Ivano-Frankivsk, Ukraine
}

\section{THEORETICAL FOUNDATIONS AND TASKS OF RECOGNITION OF HARMONIC SIGNALS AND IMAGES ON THE BASIS ESTIMATION OF HEMMING DISTANCE}

Special transitional modes and the possibility of damage to the equipment of electric and transformer substations may occur during the operation of high-voltage transmission lines. This leads to mechanical failure of the technological equipment by short circuit currents or arc that occurs at the site of the damage. Special devices for the recognition of harmonic signals and images based on the Hamming distance are successfully used to solve such problems. They are used in the case of perturbations in high-voltage transmission lines such as charges, short to ground and the launch of powerful electrical appliances. The block diagram of the device for identification of charges, short to ground and the launch of powerful electric drives in the transmission lines is proposed in the paper. Time charts of straightened values of phase voltage, current and phase difference at charges, short circuits and the launch of powerful electrical appliances in high voltage transmission lines, are calculated. The structure of the pulse special processor on the basis of the threshold integral quadrant is characterized. The structural scheme of a special processor for determining the Hamming distance in the Rademacher theoretic-numerical basis is developed. An example of the structure of a correlation special processor for recognizing and determining the distance to the source of an acoustic signal, which is given at the polygon of a two-dimensional Hamming space in Cartesian coordinates, is shown. The structural scheme of the device for determining the Hamming distance between two signals in the number-theoretic basis of Rademacher and Haar is developed. The development of a special processor for determining the Hamming distance in the number-theoretic basis of Haar-Kresterson is a promising direction for the development of devices for the recognition of harmonic signals and images based on the estimation of the Hamming distance in the case of perturbations in high-voltage transmission lines such as charges, short to ground and the launch of powerful electrical appliances. Such a special processor is characterized by significantly faster performance compared with existing analogues.

Keywords: power transmission lines; special processor; number-theoretic basis; source of acoustic signals; relay protection. 